Karamina, H. • A.T. Murti · T. Mudjoko

\title{
Analisis kandungan logam berat aluminium (Al), dan timbal (Pb) pada buah jambu biji varietas kristal (Psidium guajava L.) dan tanah di desa Bumiaji, kota Batu
}

\section{Concentration analysis of heavy metals alumunium (Al) and lead (Pb) on crystal-variety guava (Psidium guajava L.) in Bumiaji, Batu city}

\author{
Diterima : 6 Oktober 2018/Disetujui : 19 Desember 2018 / Dipublikasikan : 31 Desember 2018 \\ CDepartment of Crop Science, Padjadjaran University
}

\begin{abstract}
Bumiaji region is one of tourist destination in Batu city. This area has temperature around 20 that appropriate for horticulture product including crystal guava. One of cultivation treatment for this commodity is organic fertilizer adding. Another treatment for crystal guava commonly by inorganic fertilizer and pesticide application in high dose on long duration. It will be damage problem for environment especially for soil. Thus, this study was aimed for discovering the amount of the heavy metal $\mathrm{Al}$ and $\mathrm{Pb}$ contained in the soil and Crystal Guava. This study used descriptive analytic method along with using - Atomic Absorption Spectophotometer (AAS) for testing the heavy metal. The results of this study which concerned on the content of metal of metal $\mathrm{Al}$ in $0-30 \mathrm{~cm}$ and $30-60 \mathrm{~cm}$ soil depth showed that the highest metal essence was in 11 years, 6 years, 5 years exceeded the normal limits and entered the critical threshold of heavy metals. Both types of heavy metals namely $\mathrm{Al}$ (Aluminum) and $\mathrm{Pb}$ (Lead) both at the age of 11 years, 6 years and 5 years enter the stage beyond the normal threshold of heavy metals which should be in the crystal variety guava
\end{abstract}

Keywords : Heavy metal • Crystal guava

Sari. Bumiaji merupakan kawasan wisata yang terletak di Kota Batu. Dengan suhu mencapai $20^{\circ} \mathrm{C}$ menyebabkan Bumiaji menjadi tempat

\footnotetext{
Dikomunikasikan oleh Anni Yuniarti

Karamina, H. ${ }^{1} \cdot$ A. T. Murti ${ }^{2}$. T. Mudjoko ${ }^{3}$

${ }^{1}$ Program Studi Agroteknologi, Fakultas Pertanian,

Universitas Tribhuwana Tunggadewi

2 Program Studi Peternakan, Fakultas Pertanian,

Universitas Tribhuwana Tunggadewi

${ }^{3}$ Program Studi Agroteknologi, Fakultas Pertanian, UPN

Veteran Jatim Surabaya

Korespondensi: hidayatikaramina@yahoo.com
}

pengembangan kawasan yang cocok untuk penanaman tanaman hortikultura contohnya jambu biji varietas kristal. Budidaya jambu biji varietas kristal tidak lepas dengan pemeliharaan tanaman dengan cara pengaplikasian pupuk organik maupun anorganik dan pestisida dalam jumlah banyak dan dalam jangka waktu yang panjang. Usaha-usaha peningkatan hasil produksi di atas ternyata dapat memberikan dampak kurang baik bagi lingkungan sekitar khususnya tanah. Adapun tujuan dari penelitian ini adalah mengetahui seberapa besar jumlah logam berat $\mathrm{Al}$ dan $\mathrm{Pb}$ yang berada pada tanah dan buah jambu biji varietas kristal. Penelitian ini menggunakan metode analisis Deskriptif sedangkan untuk metode analisis uji logam berat menggunakan metode Atomic Absorption Spectophotometer (AAS). Hasil dari analisa tanah dengan pengambilan sample $0-30 \mathrm{~cm}$ dan 30 $60 \mathrm{~cm}$ ditemukan bahwa logam berat $\mathrm{Al}$ di berbagai umur tanaman 11 tahun, 6 tahun, 5 tahun melebihi batas normal dan masuk kedalam ambang batas kritis logam berat. Kedua jenis logam berat yaitu $\mathrm{Al}$ (Aluminium) dan $\mathrm{Pb}$ (Timbal) baik pada umur tanaman 11 tahun, 6 tahun dan 5 tahun memasuki tahapan melebihi batas ambang normal logam berat yang seharusnya berada di bagian buah jambu biji varietas kristal

Kata kunci: Logam berat - Jambu biji varietas kristal

\section{Pendahuluan}

Desa Bumiaji baik untuk dijadikan kawasan pengembangan komoditas hortikultura terutama buah-buahan yaitu seperti jambu biji 
kristal. Tanaman jambu biji kristal pada pemeliharaannya biasa diberikan pupuk berupa pupuk organik maupun pupuk anorganik. Pemberian pestisida maupun insektisida juga sering dilakukan pada pemeliharaan agar tanaman terhindar dari hama dan penyakit. Usaha-usaha diatas ternyata dapat memberikan dampak kurang baik bagi lingkungan sekitar. Pupuk-pupuk tersebut merupakan sumber pencemaran logam berat bagi pertanaman jambu biji kristal Menurut Kidd et al., (2009) yang termasuk dalam logam berat adalah unsur logam yang memiliki bobot jenis $>5$ dan dapat membentuk garam dalam kondisi asam.

Menurut pendapat dari Liu dan Bomke (2004) sifat pencemaran logam berat dikelompokan menjadi 3 bagian, yaitu sifat toksik tinggi yang terdiri dari unsur-unsur logam seperti Kadminium, Timbal, Seng dan Tembaga, bersifat toksik sedang yang terdiri dari unsur-unsur logam seperti Crome, Nikel, Cobalt, Aluminium dan bersifat toksik rendah yang terdiri dari unsur Mangan dan Besi. Jika logam berat terus menerus mencemari tanah, maka cepat atau lambat logam berat yang berada pada tanah akan menjadi tidak seimbang dan kemudian akan terserap dengan mudah oleh tanaman melalui akar selanjutnya jika sistem pertahanan dari akar melemah maka akan terdistribusi kebagian tanaman lainnya seperti batang dan daun (Fonte dan Quansah, 2009).

Tanaman jambu biji kristal dapat mengakumulasikan logam berat ke dalam buahnya. Adanya logam berat dalam jambu biji kristal dapat berbahaya bagi kesehatan. Salah satu logam berat yang dapat memberikan efek berbahaya bagi kesehatan adalah $\mathrm{Pb}$. Menurut Palar (2008) kadar normal $\mathrm{Pb}$ dalam darah orang dewasa $<40 \mathrm{ppm}$. Gejala kronis ringan dari keracunan $\mathrm{Pb}$ yang ditemukan pada manusia berupa insomnia dan beberapa macam ganggunan lainnya.

\section{Bahan dan Metode}

Penelitian dilaksanakan di perkebunan jambu biji var kristal, Bumiaji Sejahtera, Kota Batu, Provinsi Jawa Timur, berada pada ketinggian tempat $\pm 150 \mathrm{~m}$ dpl dengan suhu rata- rata $20^{\circ} \mathrm{C}$, kelembapan udara rata-rata $78 \%$ dan curah hujan $200 \mathrm{~mm} /$ hari. Penelitian dilaksanakan pada bulan Mei sampai dengan Agustus 2017.
Alat yang digunakan dalam penelitian ini ialah $\mathrm{pH}$ meter, sekop, tali rafia, meteran, spidol boardmarker, plastik contoh, gunting, botol contoh, sepatu boat dan kamera, blender, corong, gelas beaker, hot plate, kertas saring, kurs porselen, labu digesti, labu ukur $100 \mathrm{ml}$ dan $250 \mathrm{ml}$, pipet volume, spektrofotometer serapan atom (SSA), tanur dan timbangan analitik. Bahan yang digunakan untuk penelitian ialah tanaman jambu biji varietas kristal tahun ke 11, tahun ke 6 dan tahun ke 5. Bahan untuk pengujian logam berat pada buah dan tanah yaitu aquadest, $\mathrm{HCl}$ pekat, $\mathrm{H}_{2} \mathrm{SO}_{4}$ pekat, $\mathrm{HNO}_{3}$ pekat, $\mathrm{KMnO}_{4}$ dan hidroksilamin $\left(\mathrm{NH}_{2} \mathrm{OH}\right)$.

Metode yang dighunakan dalam penelitian ini adalah metode pengambilan sample untuk memperoleh data primer untuk analisa kandungan logam berat pada buah jambu biji varietas kristal serta tanah kebun jambu biji varietas kristal yang diambil dari beberapa sampel yang berbeda sesuai dengan perbedaan umur tanaman. Buah yang dipakai untuk analisis adalah buah layak konsumsi yang berumur 90 hari setelah muncul bunga. Analisis laboratorium mengenai kandungan logam berat dengan memberikan beberapa penarikan sampel yaitu:

A1 : Jambu biji varietas kristal dengan umur tanaman 11 tahun

A2 : Jambu biji varietas kristal dengan umur tanaman 6 tahun

A3 : Jambu biji varietas kristal dengan umur tanaman 5 tahun

Setiap petak sampel memiliki luasan yaitu $5 \times 5 \mathrm{~m}$. Pengambilan sampel tanah dilakukan tiap perlakuan sedalam $0-30 \mathrm{~cm}$ dan $30-60 \mathrm{~cm}$. Sedangkan untuk pengambilan sampel buah jambu biji kristal adalah sebanyak 2 buah per pohon. Cara penentuan sampel yaitu dengan metode acak sederhana (simple random sampling) dan setiap penarikan sampel diulang sebanyak dua kali. Sampel kemudian dianalisis di laboratorium dengan menggunakan alat Spektofotometer Serapan Atom (SSA).

\section{Hasil dan Pembahasan}

Analisa logam berat $\mathrm{Al}$ dan $\mathrm{Pb}$ pada tanah. Tabel 1. Menunjukkan hasil analisis logam berat pada tanah pada kedalaman $0-30 \mathrm{~cm}$ dengan berbagai macam umur tanaman jambu biji varietas kristal yaitu pada umur 11 tahun, 6 tahun dan 5 tahun. Ada 2 jenis logam berat yang dianalisa yaitu $\mathrm{Al}$ 
dan $\mathrm{Pb}$. Dari pengambilan sample tanah di berbagai umur variasi perkebunan jambu biji varietas kristal ini hasil dari kontaminasi logam berat di masing-masing sangat berbeda-beda. Pada unsur logam $\mathrm{Pb}$ rata-rata kontaminasi logam berat tertinggi pada umur tanaman pada lahan jambu biji varietas kristal umur 11 tahun. Sedangkan, pada unsur logam berat Al tertinggi ditemukan pada umur tanaman di lahan jambu biji varietas kristal 5 tahun.

Tabel 1. Konsentrasi logam berat $\mathrm{Al}$ dan $\mathrm{Pb}$ dalam tanah pada perkebunan jambu biji varietas kristal umur 11, 6, 5 tahun $(0-30 \mathrm{~cm})$.

\begin{tabular}{ccc}
\hline Kode & $\mathrm{Al}$ & $\mathrm{Pb}$ \\
\cline { 2 - 3 } & & $\mathrm{ppm}$ \\
\hline 11 tahun / PHN 1. & 30.5 & 5.5 \\
11 tahun / PHN 2. & 24.2 & 0.45 \\
11 tahun / PHN 3 & 37.45 & 1.27 \\
11 tahun / PHN 4 & 17.8 & 2.01 \\
11 tahun / PHN 5 & 23.6 & 1.65 \\
Rata-rata & 26.71 & 2.176 \\
6 tahun / PHN 1 & 15.2 & 1.45 \\
6 tahun / PHN 2 & 25.2 & 2.3 \\
6 tahun / PHN 3 & 28.8 & 1.24 \\
6 tahun / PHN 4 & 16.35 & 0.87 \\
6 tahun / PHN 5 & 46.8 & 0.92 \\
Rata-rata & 26.47 & 1.356 \\
5 tahun / PHN 1 & 31.6 & 3.01 \\
5 tahun / PHN 2 & 53.2 & 0.36 \\
5 tahun / PHN 3 & 35.3 & 0.02 \\
5 tahun / PHN 4 & 2.3 & 0.89 \\
5 tahun / PHN 5 & 54.4 & 1.26 \\
\hline Rata-rata & 35.34 & 1.108 \\
\hline
\end{tabular}

Dampak negatif lain dari logam berat pada tanah adalah keracunan pada proses biologi meliputi berbagai proses yang dikatalisasi oleh mikroorganisme. Komunitas mikrobia dapat dijadikan indikator hilangnya atau berubahnya kualitas tanah akibat tercemar logam berat atau perubahan mutu tanah. Hal ini dapat terjadi pada penggunaan agrokimia yang berlebihan seperti pupuk dan pestisida, begitu juga akibat dari kegiatan penambangan.

Penggunaan pupuk yang digunakan dalam budidaya pertanian dapat menyebabkan pencemaran pada tanah, karena pupuk tersebut mengandung logam berat. Dalam pertumbuhannya, tanaman menyerap unsur hara dari dalam tanah, termasuk logam berat, sehingga produk atau hasil pertanian dapat mengandung logam berat. Logam Aluminium merupakan unsur logam yang memiliki sifat-sifat yang mirip dengan unsurunsur seperti $\mathrm{Pb}$, oleh karena itu terjadi kompetisi yang kuat diantara logam tersebut dalam proses penyerapan dan translokasi hara dalam tanaman (Marschener, 2002). Hal tersebut kemungkinan menghambat penyerapan unsur hara essensial dalam tanaman. Menurut Rahma et al., (2010) gejala toksisitas atau tercemar mirip dengan tanaman yang menderita kekurangan hara dan menunjukkan gejala defisiensi yang nyata. Gejala yang serupa juga terjadi pada penelitian tanaman cucumber (Azis et al., 2007) Beberapa uraian perihal kontaminasi yang berada pada bagian tanaman dipengaruhi oleh media tanam.Sehingga media tanam yang baik merupakan media tanam yang sedikit unsur logam berat.

Sampai saat ini, belum ada nilai ambang batas konsentrasi logam berat di dalam tanah yang aman bagi produk pertanian yang dihasilkan. Konsentrasi logam berat yang sedikit, baik di dalam tanah maupun dalam produk/hasil pertanian harus mendapat perhatian yang serius. Pestisida yang digunakan dalam budidaya pertanian meninggalkan residu pada tanah, air, biji atau buah, dan tanaman, bahkan sampai badan air/sungai dan perairan umum. Namun demikian dalam konsentrasi sangat rendah, logam berat akan terakumulasi di dalam tubuh mahluk hidup, dan lambat laun akan berpengaruh buruk terhadap kesehatan.

Tabel 2. Konsentrasi logam berat $\mathrm{Al}$ dan $\mathrm{Pb}$ dalam tanah pada perkebunan jambu biji varietas kristal umur 11, 6, 5 tahun $(30-60 \mathrm{~cm})$.

\begin{tabular}{ccc}
\hline Kode & Al & Pb \\
\cline { 2 - 3 } & \multicolumn{2}{c}{ ppm } \\
\hline 11 tahun / PHN 1. & 40.80 & 7.50 \\
11 tahun / PHN 2. & 34.40 & 1.54 \\
11 tahun / PHN 3 & 49.40 & 2.22 \\
11 tahun / PHN 4 & 27.90 & 3.67 \\
11 tahun / PHN 5 & 36.50 & 2.56 \\
Rata-rata & 37,8 & 3,498 \\
6 tahun / PHN 1 & 19.30 & 2.48 \\
6 tahun / PHN 2 & 30.10 & 3.50 \\
6 tahun / PHN 3 & 38.70 & 2.22 \\
6 tahun / PHN 4 & 23.60 & 1.29 \\
6 tahun / PHN 5 & 51.60 & 1.37 \\
Rata-rata & 32.66 & 2.172 \\
5 tahun / PHN 1 & 40.80 & 4.01 \\
5 tahun / PHN 2 & 60.20 & 1.63 \\
5 tahun / PHN 3 & 45.10 & 0.44 \\
5 tahun / PHN 4 & 6.60 & 1.29 \\
5 tahun / PHN 5 & 62.30 & 2.65 \\
\hline Rata-rata & 43 & 2.004 \\
\hline
\end{tabular}

Manusia yang mengkonsumsi hasil atau produk pertanian yang mengandung residu 
pestisida, dalam jangka panjang diperkirakan akan terkena dampak berupa kanker (sebagian besar pestisida bersifat karsinogenik), gangguan metabolisme steroid akibat endocrine disrupting pesticides (EDPs), fungsi tiroid, spermatogenesis, hormon gonadotropik, aktivitas oestrogenik, dan aktivitas anti-androgenik (Squires, 2001).

Pencemaran tanah oleh $\mathrm{Pb}$ lebih luas dibandingkan logam berat lainnya. Hal ini karena sumbangan terbesar adalah dari sumber antropogenik. Dari hasil penelitian (Miller and Donahu, 2013) diketahui bahwa $\mathrm{Mn}, \mathrm{Co}, \mathrm{Fe}, \mathrm{Cr}$, dan Ni di permukaan tanah terutama berasal dari sumber lithogenic. Sedangkan $\mathrm{Hg}$ dan As di tanah dikendalikan oleh sumber lithogenic dan antropogenik. Daerah urban lebih beresiko terkena dampak pencemaran logam berat dibandingkan dengan daerah industri.

Hasil ini menunjukkan kebutuhan yang signifikan untuk pengembangan strategi pencegahan pencemaran dan pengurangan pencemaran logam berat untuk daerah yang mengalami industrialisasi dan urbanisasi cepat. Akumulasi logam berat dapat menurunkan kualitas tanah, mengurangi hasil panen dan kualitas produk pertanian, dan sehingga berdampak negatif terhadap kesehatan manusia, hewan, dan ekosistem (Nagajyoti et al. 2010).

Konsentrasi kandungan logam berat pada tanah di kedalaman $30-60 \mathrm{~cm}$ pada berbagai umur jambu biji varietas kristal bervariasi (Tabel. 2). Kandungan logam berat Al tertinggi terdapat pada tanah di perkebunan jambu biji varietas kristal umur 5 tahun. Sedangkan kandungan logam berat $\mathrm{Pb}$ tertinggi yaitu pada tanah di perkebunan jambu biji varietas kristal umur 11 tahun. Dari kedua logam berat tersebut setelah dibandingkan dengan studi literatur menurut Ministry of State for Population and Environment of Indonesia, (1992) mengutarakan bahwa nilai diatas melebihi ambang batas normal yang seharusnya. Dan dari data diatas perbedaan kedalam tanah ternyata berpengaruh terhadap konsentrasi unsur-unsur yang dikandungnya. Sebagian besar konsentrasi unsurunsur dengan kedalam tanah 30-60 cm lebih tinggi dibandingkan dengan kedalaman 0-30 $\mathrm{cm}$.

Beberapa penyebab masuknya logam berat dalam tanah yaitu antara lain asap dari kendaraan bermotor yang tidak terkontrol, pupuk organik yang tidak tepat komposisinya bagi tanaman karena dipengaruhi oleh sumber dari bahan organik yang dipergunakan sebagai bahan dasar pembuatan pupuk organik, proses pengolahan bahan bakar minyak yang terus menerus, penggunaan pupuk dan pestisida secara berlebihan, sisa -sisa buangan dari limbah rumah tangga dan industri serta pertambangan liar yang tidak terolah dengan baik dan bijaksana (Charlena, 2004).

Selain itu jika logam berat terus menerus mengalami penambahan yang terlalu banyak maka cepat atau lambat akan mengganggu keberadaan mikroba antagonis yang berada didalamnya atau bahkan dapat meracuninya (Aiyen, 2005). Oleh karena itu, diperlukan kebijaksanaan serta pengetahuan yang cukup untuk proses pemupukan sehingga baik untuk tanah maupun tanaman serta tidak mencemari lingkungan. Hal ini akan mempengaruhi dampak dari kelestarian lingkungan yang cepat atau lambat akan menunjang peningkatan pertumbuhan dan hasil produksi tanaman serta kualitas tanaman yang akan mempengaruhi kesehatan hidup manusia (Sutanto, 2002).

Hasil dari analisa tanah dengan pengambilan sample $0-30 \mathrm{~cm}$ dan $30-60 \mathrm{~cm}$ ditemukan bahwa logam berat $\mathrm{Al}$ di berbagai umur tanaman 11 tahun, 6 tahun, 5 tahun melebihi batas normal yang dianjurkan oleh Barchia (2009). Beberapa jenis tanah mampu menunjukkan sifat dan karakter tanah yang spesifik dan yang membedakan dari yang lainnya. Tanah tropis didominasi oleh Ultisol yang memiliki muatan berubah yang berbeda dengan tanah di subtropis dilihat dari asal muatannya. Tanah di tropis dicirikan dari tanah liat yang beraktivitas rendah dan didominasi oleh oksida dan hidroksida Fe dan Al. Berbeda dengan tanah tropis, pada tanah jenis subtropis didominasi oleh Mollisol, Alfisol, Vertisol, yang dapat dicirikan oleh jenis liat beraktivitas tinggi. Ciri yang berbeda ini mengakibatkan berbedanya ketersediaan hayati logam berat pada tanah Ultisol dan Oksisol dengan tanah Alfisol, Mollisol dan Vertisol (Naidu and Bolan, 2008).

Analisa logam berat $\mathrm{Al}$ dan $\mathrm{Pb}$ pada buah. Pada Tabel 3 menunjukkan bahwa kandungan logam berat $\mathrm{Al}$ dan $\mathrm{Pb}$ tinggi. Pada kandungan logam berat $\mathrm{Al}$ tertinggi yaitu pada umur buah tanaman jambu biji varietas kristal 6 tahun. Untuk logam berat $\mathrm{Pb}$ pada buah umur jambu biji varietas kristal 11 tahun. Menurut Lahuddin, (2007) jika konsentrasi logam berat pada tanah tinggi maka akan mempengaruhi tingginya 
kandungan logam berat pada bagian tanaman. Pada hasil Tabel 12 Timbal $(\mathrm{Pb})$ pada umur tanaman 11 tahun memiliki kandungan logam berat melebihi ambang batas normal. Jika buah tersebut dikonsumsi secara terus menerus dalam jangka panjang akan menyebabkan manusia akan mengalami dampak kesehatan.

Pada khususnya logam berat Timbal $(\mathrm{Pb})$ sebagian besar diakumulasi oleh organ tanaman, yaitu daun, batang, akar dan akar umbi-umbian (bawang merah). Perpindahan timbal dari tanah ke tanaman tergantung komposisi dan $\mathrm{pH}$ tanah. Konsentrasi timbal yang tinggi (0,1-10 ppm) akan mengakibatkan pengaruh toksik pada proses fotosintesis dan pertumbuhan tanaman (Charlena, 2004). Logam Pb bersifat toksik pada manusia dan dapat menyebabkan keracunan akut dan kronis. Keracunan akut biasanya ditandai dengan rasa terbakar pada mulut, adanya rangsangan pada sistem gastrointestinal yang disertai dengan diare. Sedangkan gejala kronis umumnya ditandai dengan mual, anemia, sakit di sekitar mulut dan dapat menyebabkan kelumpuhan (Darmono, 2006).

Tabel 3. Hasil analisa buah $\left(\mathrm{HNO}_{3}+\mathrm{HClO}_{4}\right)$.

\begin{tabular}{ccc}
\hline Kode & $\mathrm{Al}$ & $\mathrm{Pb}$ \\
\cline { 2 - 3 } & \multicolumn{2}{c}{$\mathrm{ppm}$} \\
\hline 11 tahun & 365.00 & 51.81 \\
6 tahun & 559.00 & 0.11 \\
5 tahun & 473.00 & 0.96 \\
\hline
\end{tabular}

Fardiaz (1992) menambahkan bahwa daya racun dari logam ini disebabkan terjadi penghambatan proses kerja enzim oleh ion-ion $\mathrm{Pb} 2+$. Penghambatan tersebut menyebabkan terganggunya pembentukan hemoglobin darah. Hal ini disebabkan adanya bentuk ikatan yang kuat (ikatan kovalen) antara ion-ion $\mathrm{Pb} 2+$ dengan gugus sulphur di dalam asam-asam amino. Untuk menjaga keamanan dari keracunan logam ini, batas maksimum timbal dalam makanan laut yang ditetapkan oleh Departemen Kesehatan RI dan FAO adalah sebesar 2,0 ppm. Pada organisme air kadar maksimum $\mathrm{Pb}$ yang aman dalam air adalah sebesar 50 ppb (EPA, 1973).

Keberadaan unsur logam pada tanah dapat terjadi karena berbagai hal yaitu penggunaan bahan agrokimia (pupuk, pestisida dan fungisida), polusi (asap kendaraan bermotor), penggunaan bahan bakar minyak, pupuk organik, buangan limbah rumah tangga, industri, dan pertambangan sehingga terjadi kontaminasi logam-logam pada tanah dan tumbuh-tumbuhan (Alloway, 1995).

\section{Kesimpulan}

1. Pada pengambilan sample tanah dengan kedalaman 0-30 cm (top soil) di umur perkebunan jambu biji varietas kristal 11 tahun, 6 tahun dan 5 tahun ditemukan bahwa unsur logam $\mathrm{Pb}$ rata-rata kontaminasi logam berat tertinggi yaitu pada umur tanaman lahan jambu biji varietal kristal 11 tahun. Sedangkan, pada unsur logam berat Al tertinggi ditemukan pada umur tanaman di lahan jambu biji varietas kristal 5 tahun.

2. Pada kedalaman $30-60 \mathrm{~cm}$ pengambilan sample tanah kandungan logam berat $\mathrm{Al}$ tertinggi terdapat pada tanah di perkebunan jambu biji varietas kristal umur 5 tahun. Sedangkan kandungan logam berat $\mathrm{Pb}$ tertinggi yaitu pada tanah di perkebunan jambu biji varietas kristal umur 11 tahun.

3. Hasil dari analisa tanah dengan pengambilan sample $0 \mathrm{~cm}$ dan $30 \mathrm{~cm}$ ditemukan bahwa ketiga logam berat Al di berbagai umur tanaman 11 tahun, 6 tahun, 5 tahun melebihi batas normal dan masuk kedalam ambang batas kritis logam berat.

4. Kedua jenis logam berat yaitu $\mathrm{Al}$ (Aluminium) dan $\mathrm{Pb}$ (Timbal) baik pada umur tanaman 11 tahun, 6 tahun dan 5 tahun memasuki tahapan melebihi batas ambang normal logam berat yang seharusnya berada di bagian buah jambu biji varietas kristal

\section{Ucapan Terima Kasih}

Ucapan terima kasih ditujukan kepada DRPM Dikti yang telah membiayai penelitian ini. Universitas Tribhuwana Tunggadewi telah memberikan kesempatan untuk melaksanakan penelitian. Fakultas Pertanian khususnya PS. Agroteknologi tempat dimana penulis mengabdikan diri guna meningkatkan kualitas dan kuantitas. Suami dan keluarga yang mendukung penulisan jurnal ini. 


\section{Daftar Pustaka}

Aiyen. 2005. Ilmu remediasi untuk atasi pencemaran tanah di Aceh dan Sumatera Utara. Harian Kompas 4 Maret 2005.

Alloway, B. J. 1995. The Origins of heavy Metals in Soils. In B. J. Alloway (Ed.) heavy Metals in Soils, Blackie Academic and professional pp. 38 - 57.

Azis, E. E., N. Gad. and N. M. Badren. 2007. Effect of plumbum and aluminium on plant growth system of quercus ilex trees and effects of selected ligands present in the xylem sap. Journal of Plant physiology. 166 (2) : 270-277.

Barchia, M.F. 2009. Agroekosistem Tanah Mineral Masam. Gadjah Mada University Press. Yogyakarta

Charlena. 2004. Pencemaran logam berat Timbal $(\mathrm{Pb})$ dan Cadmium (Cd) pada sayur sayuran. http:// www. rudyct. com/ PPS702 ipb/09145/charlena.pdf. Diakses tanggal 29 November 2011

Darmono. 2006. Lingkungan Hidup dan Pencemaran: Hubungannya Dengan Toksikologi Senyawa Logam. UI Press. Jakarta. p. 25-50.

Environmental Protection Agency [EPA]. 1973. Water Qualitiy Criteria. EPA. Ecology Research Series. Washington.

Fardiaz, S. 1992. Polusi Air \& Udara. Kanisius. Yogyakarta

Fonte, S. J. and E. Y. Quansah. 2009. Fertilizer and residue quality effects on organic matter stabilization in soil aggregates. J. of Soil Science. 73 (1): 961-966

Kidd, P., J. Barcelo., M. P. Bernal., F. Navari Izzo., C. Poschenrieder., S. Shilev., R. Clemente. and C. Monterrose. 2009. Trace element behavior at the root soil interface. Implication in phytoremediation. Journal Enviromental and Experimentl Botany. 67(1) : 243-259.aaaa

Lahuddin, M. 2007. Aspek unsur mikro dalam kesuburan tanah. USU Press. Medan
Liu, A. and A. A. Bomke. 2004. Effect of cover crops on soil aggregate stability, total organic carbon and polysacharides. J. Soil Science. 69 (1): 2041-2048.

Marschener, H. 2002. Mineral nutrition of higher plant. San diego, Ca. Academic Press London. p.902.

Ministry of state for popultion environment of Indonesia and Dalhouse. 1992. Phytoremediation of heavy metals. University Canada. Plant and Soil Corp. p. 120-125.

Miller, M. H. and R. L. Donahu. 2013. Soils an introduction to soils and plant growth. Prentice Hall Englewood Cliffs. New Jersey. p. 768.

Nagajyoti P.C., Lee K. D. and Sreekanth, T.V.M . 2010. Heavy metals, occurrence and toxicity for plants: a review. Environ Chem Lett 8 (3):199-216

Naidu, R., R and N. S. Bolan. 2008. Contaminant chemistry in soils : Key concepts and bioavaiblability. In chemical bioavailabilitiy in Terrestrial environment, ed. R. Naidu. Elsevier, Amsterdam the Netherlands, pp. 9-38

Palar, H. 2008. Pencemaran dan Toksikologi Logam Berat.Jakarta: PT Rineka Cipta Palar, Heryando. 2008. Pencemaran dan Toksikologi Logam Berat. PT Rineka Cipta. Jakarta.

Palar, H. 2008. Pencemaran dan Toksikologi Logam Berat. PT. Rineka Cipta. Jakarta.

Rahma, H., S. Sabreen., S. Alam and S. Kawa. 2010. Effects of aluminium ongrowth and composition of metal micronutrients in barley plants grown in nutrient solution. Journal of Plant Nutrition. 28 (2): 393-404

Sutanto, R. 2002. Penerapan pertanian organik pemasyarakatan dan pengembangannya. Kanisius. Yogyakarta

Squires, V. R. 2001. Soil pollution and remediation: issues, progress and prospects. Di dalam: Prosiding Workshop Vegetation Recovery in Degraded land Areas. Kalgoorlie, Australia, 27 Okt-3 Nov 2001. hlm 11-20 